\title{
Appropriateness and Adequacy of Teaching and Learning Resources and Students' Industrial Attachment in Public Colleges of Technical and Vocational Education in Zambia
}

\author{
${ }^{1}$ Innocent Mutale Mulenga, $\mathrm{PhD}^{*}$ and ${ }^{2}$ Edward King Chileshe \\ ${ }^{1}$ Lecturer of Curriculum Studies and Teacher Education, The University of Zambia \\ ${ }^{2}$ Teacher, Nyimba Secondary School, Zambia \\ *Corresponding author: innocent.mulenga@unza.zm
}

\begin{abstract}
Zambia has the largest youthful population of below 15 and 18 years which constitute $45.5 \%$ and $52.5 \%$ of the total population respectively. This is expected to rise by 2030 . However, this huge number of young persons, which should be a great resource for economic development, is mostly unemployed (UNESCO, 2016). For many years now the government of the Republic of Zambia has been running and introducing more Vocational Education and Training Institutions as a way of reducing unemployment amongst young people. Regardless of all these efforts, most youths in Zambia who have graduated from such institutions remain unemployed (TEVETA, 2015). In this study, the researchers investigated the appropriateness and adequacy of institution's teaching and learning resources that the students were exposed to during trainings and how the industrial attachments were organized by the Technical Vocational Education and Training (TVET) institutions. The mixed method research approach was used to analyze this phenomenon. Six college principals were purposively sampled while stratified and simple random sampling were used to sample sixty lecturers, ten from each of the six colleges. Findings showed that TVET institutions in Zambia were plagued with a number of challenges ranging from lack of appropriate and modern workshop equipment, lack of reading material and ineffective industrial attachment. Researchers recommend that the Ministry of Higher Education and college managements should provide a conducive learning environment in these institutions if graduates were to acquire the required technical competencies.
\end{abstract}

Key words: Industrial attachment, Teaching and Learning Resources, Vocational Education and Training.

\section{Introduction}

Technical Vocational Education and Training (TVET) plays a critical role in providing hands-on education and thus contributing to the economic development of both developed and developing countries. In fact, if well planned, TVET can greatly contribute to the achievement of most of the Sustainable Development Goals that the world has set for itself as a means to the vision 2030 plan. Additionally, TVET has been recognized as a sure means of sustainable economic development and social and political development of a nation since the type of education provided by TVET institutions directly empowers students with employable and potentially self-sustaining skills, knowledge, values and attitudes (Ministry of Education, 1996, TEVETA, 2016, and Sharma, 2008). Finland has been making positive headlines in the education news as being one of the countries providing quality education to its citizens. In the country, Vocational Education and Training (VET) and vocational competence have been very instrumental in the promotion of economic competitiveness and prosperity as explained by Sahlberg (2012). The development of VET is rooted on the mass expectation of long-term demand for labor and educational needs and the quality of skills required in a nation. From the Finish experience of VET, one may be tempted to easily conclude that, technical and vocational education

30 East African Journal of Education and Social Sciences (EAJESS) 1(2)30-42 
and training come with the sole aim of training the individual to acquire the knowledge and the technical skills required to usher him or her into the job market and most likely be self-employed.

However, TVET institutions in Zambia seem to be failing to produce the much needed skilled human resource, such as artisans, craftsmen/women, technicians and technologists (TEVETA, 2015). The 2008 Zambia TEVET policy document itemized a number of challenges that TVET institutions have been going through such as lack of staff development policies, stagnation in the provision of infrastructure, lack of teaching and learning resources, poor conditions of services for staff, negative perception and weak management systems. However, these challenges have not been analyzed in terms of how they have been affecting the TVET core business of helping students to acquire relevant competencies through technical programs. On the other hand, the unemployment and poverty among the trained people are still very high in Zambia and in other African countries as noted by UNESCO (2016). In particular, in 2016, the overall youth unemployment rate in Zambia was at 10.5 percent, with higher youth unemployment rates of 17.1 and 13.8 percent observed in age groups of 15 to 19 and 20 to 24 , respectively. In the same context, it was confirmed that, the issue of poverty among the youths in developing countries, particularly in Zambia, was growing steadily, leading to an increase in the size of a poor society (Republic of Zambia, 2017). Can Technical Vocational Education and Training (TVET) help the situation, given that its main focus is to empower young people with technical competencies? Incidentally, Zambia is currently experiencing an explosion of people acquiring university degree qualifications but have few, if any, employability competencies despite the country having introduced a competency based curriculum since 2013 and thus the establishing of the Higher Education Authority will help normalize this situation (Simukanga and Jacob, 2018). No wonder Zulu and Mulenga (2019, p. 277) rightly explained that 'the way a curriculum is conceptualized in theory and then designed, organized and developed for practical implementation depends on a country's particular philosophy of education'. Fortunately, the Zambian philosophy of education is guided by principles of a competency-based curriculum which is also the basis for the TVET education.
In the context of TVET in Zambia, studies have been conducted to analyze the availability and the use of teaching and learning resources which include; workshop equipment, facilities, the curriculum, text books and other technical literature (Salimu, 2007, Kigwiru, 2014, Hamweete, 2008, Dadi, 2014 and Mwila, 2016). However, these studies did not address the use of teaching and learning resources. Additionally, despite many scholars, learners and employers across the globe agreeing that the workplace is the most authentic learning environment to train a competent workforce (UNESCO, 2016 \& Wallernborn, 2010) industrial attachment in Zambia seems not to have been given its deserving attention by TVET institutions.

This paper is part of a study that was conducted on students' competency acquisition in TVET institutions in Zambia. For the sake of this article, researchers focused on sharing how teaching and learning resources and industrial attachment were appropriate for the various technical programs. The research questions that the researchers sought to answer were as follows.

1. How adequate and appropriate were the teaching and learning resources in Public Colleges of Technical and Vocational Education in Zambia?

2. How adequate is the industrial attachments among Public Colleges of Technical and Vocational Education in Zambia?

It is clear with most scholars and ministries of education around the globe that the purpose of technical and vocational education and training is basically to provide individuals with needed competencies for socio-economic and industrial development. Thus a country like Zambia which is blessed with an abundance of natural resources and the cultural diversity, should experience good economic growth and benefits. One then wonders why the opposite reality prevails.

\section{Related Literature and Studies}

One of the key purposes of Technical Vocational Education and Training is to help students acquire hands on skills in various areas of specialization. However, Umunadi (2011) explained that in Nigeria one of the issues of great concern among Technical Vocational Education and Training (TVET) educators is that of the poor state of workshop tools and equipment in TVET institutions. Umar and Ma'aji (2010) also stated that most of the TVET institutions 
in the country had been forced to perform below standard due to the non-availability, poor management or utter neglect of the required facilities in the workshops for effective skills acquisition and limited financial support from the government. Additionally, in his doctoral study about TVET curriculum in Ethiopia, Dadi (2014) noted that most institutions in Oromia Regional State had challenges with the provision of modern workshop equipment and tools. The Nigerian and Ethiopian situation prompted the researchers in this study to find out what the situation could be in Zambia given that these countries seemed to have something in common in relation to this matter. In the same context, Barky (2005) and Kigwilu and Akala (2017) in Kenya reported that lack of equipment and workshop tools in TVET institutions made the country impossible for students to receive training that met the standards for employment in industries or related organizations. Barky (2005) also observed that the availability of instructional resources had a major influence on the selection of teaching methods and materials.

A study conducted by Dasmani (2011) in Ghana also suggested that appropriate teaching facilities had remained grossly inadequate in the practical training of TEVET students. The inadequacy of the facilities resulted in training sessions being undertaken without practical activities that were necessary to bring out the best of student' talents. The study discovered that most of the few tools and equipment were obsolete and outdated. The report made by Dasmani (2011) brought into question the quality of technical and vocational training offered in Ghana in view of the poor state of infrastructure which indicated a mismatch with the industrial equipment. The Kenyan, Nigerian and Ghanaian situation on this matter further strengthened the researcher's desires to investigate the Zambian situation.

Regarding Zambia, some studies have indicated that there was a serious mismatch between training equipment used during training and competence obtaining in the industry (Hamweete, 2008, Nkanza, 2007). The physical infrastructures, training materials and training equipment of most TEVET institutions were dilapidated, insufficient and worn out (Salimu, 2007, Mwila, 2016 and TEVETA 2016). In most cases graduates were given on-job-training to enable them perform to the expected standard (Nkhaza, 2008). Although, these Zambian scholars found out all this about TVET institutions, they did not directly focus on student's competency acquisitions but on the management of such institutions.

Most studies in some African countries have documented that there was a huge gap between demand and supply of skilled labour (UNESCO, 2016; Dadi, 2014 and Daksa, 2013). The skills gap between the industry and TVET students is likely to have had an adverse effect on the growth of the Zambian economy as suggested by Nkhaza (2008). TEVETA (2015) and Wallernborn (2010) who also reported that the skills gap exhibited in students particularly from TVET institution was due to the inappropriateness of training programs. For example, industrial attachment should be pivotal in TVET institutions. The skills gap could thus be overcome by students having an effective industrial attachment in reputable and advanced industries which have new technology (Ngure, 2013). Additionally, a study that was done by Keiser et al., (2004) on technical education curriculum assessment revealed that industries were the most suitable places for students to acquire competencies and practice the competencies learned at college or training institutions. As mentioned earlier, UNESCO (2016) and Wallernborn (2010) stated that, scholars, learners and employers across the globe agree that the workplace is the most authentic learning environment to train a competent workforce.

The researchers in this study had realized that most of the studies reviewed which were done in Zambia and elsewhere about TVET had mainly focused on the performance of management and did not clearly investigate the appropriateness and adequacy to the teaching and learning resources and industrial attachments.

\section{Research Methodology}

This part presents the methodology that guided the study. it addresses such issues as research design, population and sampling, data collection procedures, validity and reliability and limitations of the study.

\section{Research Design}

This study used a convergent parallel design which is sometimes referred to as convergent concurrent design. Onwuegbuzie and Frels (2013) argued that the key components of a convergent parallel approach, as with any other mixed methods approach, has to do with priority and sequence. In terms of priority, both qualitative and quantitative 
approaches were given equal weight. In terms of sequence, the researchers simultaneously collected both quantitative and qualitative data, analysed both datasets separately, and then compared the results from the analysis of both datasets and finally made interpretations. In this study the use of convergent concurrent design was eminent because the nature of the data that was collected required the use of both qualitative and quantitative approaches.
Within this design, the researcher had the opportunity through the use of qualitative approach to gather in-depth data from TEVETA officials and from college principals whereas quantitative approach facilitated the collection of data from the lecturers. These approaches complemented each other and provided the triangulation of findings and thus greater validity of the emerging inferences. Figure 1 is an illustration of how the convergent parallel design was applied in this study.

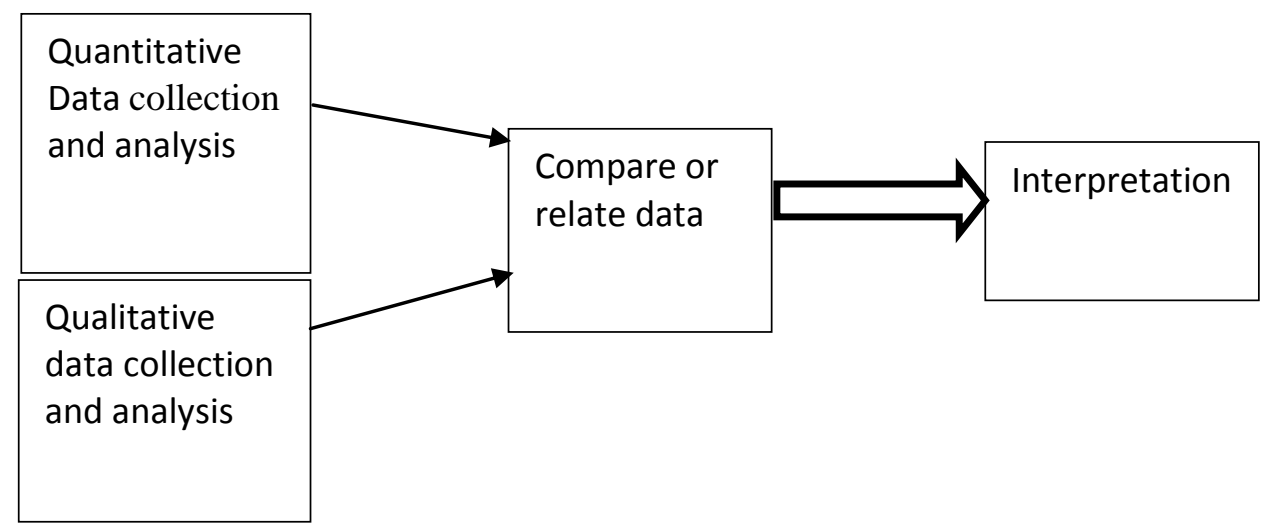

Figure 1: The Convergent Parallel Design (Adopted from Creswell, 2012)

\section{Population and Sampling}

Six government TEVET colleges that trained craftsmen and technicians in technical programs were sampled using simple random sampling from among the ten oldest colleges from the ten provinces of Zambia. Simple random sampling was preferred because it gave an equal chance of any of the colleges to be part of the sample as scholars such as Creswell and Plano Clark (2011) and Kombo and Tromp (2006) explain and justify. Two Technical Vocational Education and Training Authority (TEVETA) Directors and six college principals were purposively sampled as they were assumed to have in-depth understanding and experience regarding TVET programs in Zambia and in the colleges respectively. Using stratified sampling and then simple random sampling, sixty lecturers, ten from each of the six TVET institutions were sampled from a total population of 350 lecturers.

\section{Data Collection Procedures}

Questionnaires were used to collect information from lecturers whereas interview schedules were used to collect information from the TEVETA officials and college principals. An observation checklist was also used for triangulation so as to supplement information that was collected from interviews and questionnaires on the availability and use of teaching and learning resources and industrial attachments.

\section{Validity, Reliability and Trustworthiness}

The use of different instruments such as interview guides, an observation checklist and questionnaire helped to triangulate the data. Member checking was also used as a way of ensuring validity of what was collected from the respondents. In order to ensure reliability in this study a pilot test was conducted and responses were scrutinized to ensure that they were giving consistent responses. For instance, the questionnaire was piloted to 20 lecturers and the information was analyzed using the SPSS version 20 and the Cronbach's Alpha test was used to calculate reliability. Pallant (2007) stated that a value of 0.08 is seen as an acceptable value for Cronbach's Alpha and values lower than 0.08 indicated unreliable scale although other scholars still argue that even 0.06 would still be acceptable. Most questions in a questionnaire had indicated a Cronbach's Alpha values of 0.08 and above but the questions that had values lower than 0.08 were corrected and modified. 
Although there are arguments to accept the trustworthiness of qualitative findings, yet, criteria for ensuring rigour in this form have been in existence for many years which include credibility, transferability and confirmability (Shenton, 2004). These criteria are extremely important in a qualitative approach and the following is a description of each criteria and strategies that were employed as to meet them. Since credibility deals with the focus of the research, it refers to the idea of internal consistency which is the quality of achieving a level of performance which does not vary greatly in quality over time (Gasson, 2004). In this study, credibility was addressed by prolonged engagement with participants as well as persistent observation in the field during the research. Further, member checking and triangulation were employed as earlier explained. Transferability refers to the extent to which the reader of the particular study is able to link the findings of that study to her or his own context and addresses the core issue of "how far a researcher may make claims for a general application of their theory (Gasson, 2004). In this case, 'context' can mean similar situations, similar populations and similar phenomena (Shenton, 2004). This was ensured in this study through providing sufficient information about the research instruments, the research context and participants. In addition, Morrow (2005) suggested that since specific information is maximized in relation to the context in which the data collection occurs, it was therefore, prudent to use purposive sampling so as to ensure transferability of the research findings. Shenton (2004) defined confirmability as a degree of neutrality in the research findings. In other words, this means that the findings are based on participant's responses and not on any potential bias or personal motivations of the researcher. This also involves making sure that researchers' bias does not skew the interpretations of what the research participants said. In order to address confirmability in this study, member checking was applied by asking the interviewees to clarify some responses which could have seemed too ambiguous to the researcher.

\section{Limitations of the Study}

The technical programs whose lecturers took part in this study included, General Agriculture, Automotive Mechanics, Carpentry and Joinery, Bricklaying and Plastering, Plumbing and Sheet Metal, Electrical Engineering, Refrigeration and Air Conditioning and Computer Sciences. These programs are not the only ones that are offered in all TVET institutions in the country because other programs such as creative digital media, secretariat, health and hospitality programs were not part of the study since they were not found in the institutions that were sampled. Hence, the results of this study may not be generalized to such programs.

\section{Findings and Discussion}

In this section, the results of the study based on the two research questions are presented and discussed

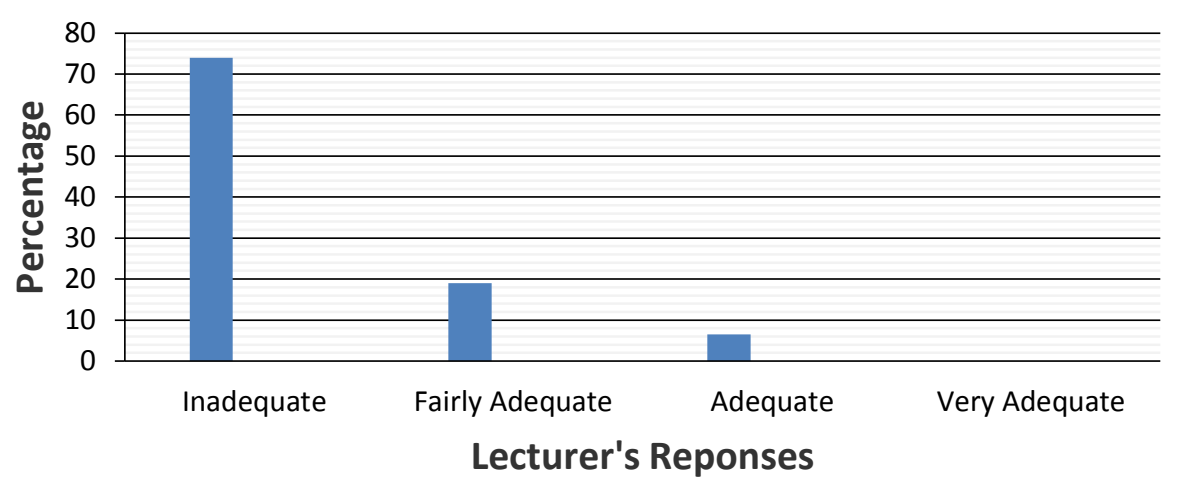

Figure 2: Lecturers' responses about the adequacy of modern workshop equipment and lecture rooms

\begin{abstract}
Adequacy and Appropriateness of Workshop equipment

Lecturers were asked to indicate on a four point Likert scale about the adequacy of modern workshop equipment. The scale was rated as; 4=Very Adequate, 3 = Adequate, 2 =Fairy Adequate,
\end{abstract}

$1=$ Inadequate. College principals and directors were also interviewed later on. Figure 1 shows the summary of the findings from the lecturers' ratings on modern workshop equipment. As shown in figure 2 , most of the lecturers representing $74 \%$, responded that modern workshop equipment and lecture rooms were inadequate and only $6.5 \%$ indicated that they were adequate, while 19\%

34 East African Journal of Education and Social Sciences (EAJESS) 1(2)30-42 
indicated that they were fairy adequate. A follow up question was asked to lecturers to elaborate what they had indicated on the scale. The researchers took interest in the majority who indicated the inadequacy and the fairly adequate points. Most of the lecturers indicated that the colleges infrastructure and equipment had not been upgraded since they were built. For instance, one of them mentioned that;

Since the colleges were built more than 30 years ago, we have not received or bought any new and modern equipment. All the demonstration equipment we have in all the workshops are old and not in line with what is in the society and industry today. Most of the time we use videos to show students the modern equipment but students cannot practice on videos.

Another lecturer indicated that;

Lecture rooms are too small, not enough and have very uncomfortable seats for students. The workshops have ancient machines and most of them do not function any more. This is our biggest challenge because workshop demonstration facilities and machines do not reflect what is in industry. This has adverse implications on student's skills acquisition.

Similarly, all the college principals and the officials from TEVETA affirmed that the facilities and equipment that were used in TVET institutions were not adequate and appropriate to equip students with relevant skills. Principal B explained that;

As an institution, we do not have adequate as well as relevant equipment and appropriate lecture rooms to enhance students' competencies in all the technical programs. This is because the equipment are too old, they are obsolete and cannot be equated to technological advancement happening right now in the industry. In automotive mechanics that's where we have the biggest challenge, so far there is only one carburetor engine for all students to do their practical on and this engine is very old. Due to various challenges we face as an institution, we can't afford to buy new equipment that could cater for all students during workshop practical.

The other principal A also affirmed in a separate interview that;
Our biggest challenge is the lack of appropriate workshop, demonstration equipment and machines. Our student's determination to learn is hampered by this challenge. I can tell you that even the industry wonders if these students passed through vocational training institutions such as our own because they lack the needed skills.

In responding to the same question, the one of the officials from TEVETA explained that;

Most of the colleges do not have modern and appropriate equipment and enough lecture rooms. Particularly automotive, carpentry and plumbing related courses. But equipment are extremely expensive and the majority of institutions alternatively end up using obsolete equipment and facilities which are available. This is a big draw back in terms of students' acquisition of appropriate skills for their programs.

Based on the views of participants about workshop equipment and lecture rooms, TVET institutions in question had a challenge in securing latest equipment for student's practical trainings. This situation is likely to have compromised the quality of competencies that the students could have acquired at the completion of their programs. The findings are in agreement with the those of NICHE (2010) who documented that insufficient training equipment leads to trainees' overcrowding during practical demonstrations, a situation which in turn made most of the trainees to only observe the demonstration and not actually having the opportunity to get some hands on practice. The implication is that education in these institutions remain theoretical in most cases and produce graduates with lower employability capacity because they lack the competencies needed by the industries. Similarly, it seems TVET institutions have found themselves in a situation that forces them to depend on obsolete equipment which could not be easily maintained to bring them to life again due to their old nature as early observed by Umar and Ma'aji (2010), Barky (2005) and Ngure (2013). This situation has even been made worse because of the poor funding to education that the Zambia government has as Mulenga and Kabombwe (2019:126) explained: 
The implementation of the competency based curriculum is more expensive than the content based one since it demands for specialized teaching and learning resources, equipment and infrastructure in the vocational and science based study areas especially.

The findings in this study agree with most studies which were done in Zambia that TVET institutions were riddled with infrastructural challenges which included old and obsolete training equipment, shortage of workshop and classroom accommodation and poor internet connectivity (Hamweete, 2007, Mwila, 2016 and Salimu, 2007). In particular, a recent study conducted in Lusaka province by Mubanga, Hock, Karim, Senteri, Mulenga and Preckler (2019:173) report that;

The industry expert illustrated that students were being trained on old technology and old methods which are not relevant to the modern industry. The emphasis was that students should be trained using same or similar equipment, tools and technology that they will find in industry when the graduate to either go and set up their businesses or get employed, otherwise they bound to face difficulties in both instances.

As a result, this may have affected the quality of training and development of students as well as their knowledge and skills that could have made them contribute and participate in the complex rapidly changing society. Generally, inadequate and non-functional training facilities in TVET institutions may result in the poor acquisition of competencies and poor students' performance. The lack of competencies is even much more critical when it comes to growing locally managed industries. The principle of sustainable development for any country is to have locally grown skills which can lead to the establishment of indigenous industries and thus creation of employment. However, with this kind of a situation in Zambia, it is most likely that the country will have to continue to depend on foreign skilled manpower whose main aim is to make profits and ship it back to their countries. If such a situation is allowed, Zambia will continue to be used as a profit making environment by other nations such as China who have currently flooded the country with their technical skilled nationals.

\section{Teaching and Learning Materials}

Teaching and learning materials are extremely important in equipping students with various and relevant competencies and therefore it was vital in this study to assess the adequacy and appropriateness of teaching and learning materials such as students' and lecturers' text books, computers and lecture room visual aids.

Lecturers indicated their views on issues regarding teaching and learning materials on a five point Likert scale $(5=$ strongly agree, $4=$ agree, $3=$ neutral $2=$ disagree and 1 = strongly disagree) and the results were as shown in Table 1.

Table 1: Results of lecturers' rating of teaching and learning materials

\begin{tabular}{|c|c|c|c|}
\hline SN & Statements regarding teaching and learning materials & Mean & Std Dev \\
\hline 1 & $\begin{array}{l}\text { Teaching and learning materials are adequate for all students in both theory and } \\
\text { practical learning }\end{array}$ & 2.19 & 0.833 \\
\hline 2 & $\begin{array}{l}\text { Learning materials for teaching are not appropriate for the programs students are } \\
\text { doing }\end{array}$ & 3.90 & 0.790 \\
\hline 3 & $\begin{array}{l}\text { Learning materials for teaching and learning are available and enough for all the } \\
\text { programs }\end{array}$ & 2.29 & 0.732 \\
\hline 4 & $\begin{array}{l}\text { Learning equipment's and machines are not relevant to the occupation in the world } \\
\text { of work }\end{array}$ & 3.74 & 1.264 \\
\hline 5 & Learning equipment are effectively utilized during teaching by all students & 3.71 & 1.071 \\
\hline 6 & $\begin{array}{l}\text { The available lecture room and workshop equipment help to develop competencies } \\
\text { (knowledge, skills, abilities) in students }\end{array}$ & 1.87 & 0.846 \\
\hline 7 & $\begin{array}{l}\text { The college library is not stocked with current as well as appropriate lecturers' and } \\
\text { students' text books }\end{array}$ & 4.52 & 0.626 \\
\hline
\end{tabular}

The results indicate that, most of the lecturers' responses were in agreement with items expressed in Table 1. According to the lecturers' responses, learning materials were not adequate for all students for both theory and practical learning with, learning materials for teaching and learning were not appropriate for the tasks (3.90 and 0.790) and learning materials for teaching were not available 
and enough for all programs (2.29 and 0.739). This is in agreement with other scholars who suggested that the other major challenge faced by TVET institutions in implementing its curriculum was the shortage of teaching and learning materials such as textbooks, lecture rooms demonstration aids and computers (Brown, 1994, Indoshi, et al. 2010 and Mupinga, et al. 2006, Kigwiru and Akala 2017). Mwila (2016) noted that TVET institutions did not provide well stocked library facilities to the students which would affect their levels of theoretical understanding of technical concepts. This results in over reliance on old and obsolete literature thereby denying students and staff opportunities to research and familiarize themselves with more recent developments in various spheres of specializations. As expressed in item vi in table 1 students acquisition of competencies is questionable.

Similarly, all the college principals and TEVETA officials that participated in this study confirmed that teaching and learning materials were not adequate and appropriate in TVET institutions that could equip students with relevant skills needed for the labour market. College principal C explained that;

In terms of teaching and learning materials we are struggling. In some courses we have a bit while in others we do not have at all. We have only procured few recommended books for lecturers though not locally produced in each program but the problem is whether the lecturers are able to correctly interpret current books especially if they were trained twenty (20) years ago. You would discover that some institutions are still using old books because lecturers cannot interpret the content of these modern books. However, we have started a process of developing our own books that reflect our own context. Generally, learning materials are not adequate for all students and this is a challenge in implementing the existing curriculum.

When the observation checklist was used to examine teaching materials in the library, it was noted that, most textbooks that were stocked in the library and those that were used by lecturers were foreign. The implication on these foreign textbooks could be that, local authors had not either found it fit or given an opportunity to write and publish books for TVET. Since the books were bought from developed countries where the technology has advanced, lecturers found it difficult to interpret the content that might have not been reflecting the context of the country, Zambia. Additionally, TVET institutions had some challenges in securing current teaching and learning materials for the students and this could have contributed to the acquisition of poor competencies among the students.

Table 2: Responses of lecturers on TVET- industrial attachments

\begin{tabular}{llcc}
\hline SN & \multicolumn{1}{c}{ Items } & Mean & Std Dev \\
\hline 1 & $\begin{array}{l}\text { There is a supportive government policy that facilitates and encourages } \\
\text { collaboration between TVET institutions and industries }\end{array}$ & 4.68 & 0.541 \\
2 & $\begin{array}{l}\text { Skilled mentors during industrial attachment help students to acquire knowledge } \\
\text { and skills for in the program of specialization }\end{array}$ & 2.57 & 0.620 \\
3 & TVET institutions conduct tracer studies and interact closely with industries & 1.84 & 0.779 \\
4 & The time given to students for industrial attachments is adequate & 1.77 & 1.175 \\
5 & $\begin{array}{l}\text { Industries adequately incorporate all students for industrial attachments and meet } \\
\text { the demand of TVET institutions }\end{array}$ & 1.81 & 0.873 \\
\hline
\end{tabular}

\section{Industrial Attachment}

Research question two sought to establish how industrial attachments were practiced in TVET institutions as a way of enhancing the acquisition of relevant practical skills in students. Mean scores and standard deviations were used to analyze the responses from lecturer's rating of the same. The response rates were presented on a five point Likert scale of 5, 4, 3, 2 and 1 representing strongly agree, agree, neutral, disagree and strongly disagree respectively. The results presented in table 2 will help readers to understand the extent to which industrial attachment was part of the programs in TVET institutions.

The results in table 2 show that the majority of lecturers agreed with the statement that there was a supportive government policy that facilitated and encouraged collaboration between TVET institutions and industries with the mean score of 4.68 and the standard deviation of 0.541 . However, lecturers 
disagreed that skilled mentors during industrial attachments helped students to acquire knowledge and skills for their future job as represented by the mean and standard deviation of 2.57 and 0.620 respectively. The results also indicated that TVET institutions did not conduct tracer studies and interact with industries (1.84 and 0.779), the time given to students for industrial attachments was not adequate (1.77 and 1.175) and industries were not incorporating all students for industrial attachments so as to meet the demand of the TVET institutions (1.81 and 0.873).

Similarly, those interviewed, college principals and two officials from TEVETA confirmed the lecturer's views. In particular, principal $F$ explained that;

As per tradition, second year students are sent for industrial attachment. Then they come with recommendations from industries and the marks that are given are made part of continuous assessment. But we have a challenge with this arrangement (industrial attachment), because not all students are absorbed by the industries. Additionally, in the past, we used to monitor students at the time of their attachments, but because of inadequate resources, it has become very difficult to do that. The monitoring period also used to help us conduct tracer studies but all that cannot be done.

Additionally, one of the directors from TEVETA also explained that;

Industrial attachment is a vital component and a requirement in all the programs under TVET for every student to practice. However, industrial attachment is not prescribed in the TVET curriculum and much as we would like our students to do it, it's not possible. Not because of their own wish or TEVETA, but it's just due to the small industrial base in Zambia. We have few companies which can absorb all students for practice. Initially, colleges would arrange industrial attachments for students rather than just writing letters. We are lagging behind in terms of industrial practices.

Moreover, in responding to the question of industrial attachment, principal $A$ asserted that;

There is a strong will from the government as well as the Ministry of Higher Education to facilitate the linkage between our institutions and the industries. But one setback that is there is that, there is a duplication of training. You would discover that industries such as the mines and the Zambia Electricity Supply Corporation who should absorb most of our students have their own colleges to train their own personnel in the same courses we offer such as engineering, power electrical, bricklaying and plastering, and plumbing.

A TEVETA official also complained that;

Some industries were not just willing to have students attached to their companies for fear of students damaging their equipment, the demand of paying them somethings for the work done and transporting them to work. This is unfortunate and as an authority we are looking for ways to make such companies take in trainees for attachment.

This view was also shared by a number of lecturers in the open ended question in the questionnaire. As earlier mentioned, industrial attachment is key to the effective education of any vocational program. From the findings in table 2 however, it is shown that students in these vocational training institutions did not have a very effective industrial attachment exercise to the extent that some did not have it at all. This is quite worrisome in terms of students acquiring competencies in their programs of training. Without an effective industrial experience, students will not be able to link the theory that they learn in college to the practice of their trade which is the core of every vocational training program. It is for this reason that Choy and Hauka (2009) explained that industry attachments have long been identified as a core component of training for trainees and thus should be well structured and coordinated.

Additionally, Mwila (2016) stressed that it was imperative that lecturers follow their students in the field when they are on industrial placements so as to reconcile the theory learnt at the training institutions with the practical work at the industry. This would also accord the lecturers an opportunity to modify their methods of teaching and reshape them in line with the dynamics of the industrial demands. Time is one of the essential factors in practical trainings and students were supposed to

\section{East African Journal of Education and Social Sciences (EAJESS) 1(2)30-42}


be given more time during industrial attachment and this could have made them to acquire relevant competencies that were in consistent with industrial requirements.

Besides, the findings of this study also revealed that industries were not adequately incorporating all students for industrial attachments and could not meet the demand of TVET institutions. The officials from TEVETA also confirmed that, it was not possible for all students to have an opportunity to practice industrial attachment due to a small industrial base in Zambia. NICHE (2010) documented that, in developing countries, even where there is collaboration and willingness, industries do not have enough places to accommodate trainees, which cause overcrowding during traineeships. These findings have a very negative implication on the student's competency acquisition because it is in industries that students are supposed to have adequate practical trainings and effectively enhance skills on different modern equipment that could not be found in their TVET institutions as is the case in this study.

On the other hand, one of the impeccable challenges noticed was with industries rejecting students from TVET institutions. Some industries complained about equipment damage during practical trainings, inadequate resources and logistics that should be catered for students at the time of their industrial attachment which included food, transport and a token of appreciation. The findings are in line with what was reported by Ngure (2013) that production equipment would be damaged or improperly handled by inexperienced trainees and that additional equipment is needed for training in order not to disturb the regular production. In addition, accident insurance for trainees and long training periods may make enterprise participation costly. In order to avoid such accidents in industries, there is a need by TVET institutions to equip students with practical skills that could enable them adhere to safety rules and industries to assign trained experts to guide students during industrial attachment

Therefore, from the findings, the researchers noted that TVET institutions have been left sorely alone with a burden to provide competency based training and to procure equipment in all technical courses meant for practical training. By its very nature, TVET education is competency based. In a competency based curriculum learners need to demonstrate as Mulenga and Kabombwe $(2019$, p. 128) noted that 'learning in a competency-based curriculum should be visible in the learner and not simply theorized about because the Outcome-based curriculum is designed in such a way that learners demonstrate the competencies'. Ngure (2013) suggested that industries, companies and TVET institutions should share the responsibility of providing students with the best possible job qualifications. Therefore, industries have a cooperate responsibility of working with TVET providers in the training of artisans, technicians and technologists to be. This would also enable students to have an opportunity to practice on latest machines and perfect their competencies that the industries in future would depend upon. Consequently, in the long run, unemployment and poverty levels among the graduate students from TVET institutions are likely to be minimized.

\section{Conclusions and Recommendations}

Having presented and discussed the results, this section gives the conclusions and recommendations of the study.

\section{Conclusions}

It can be concluded from this study that teaching and learning resources which include workshop equipment, visual aids and text books were not adequate for all students in the TVET institutions for practical training. The inadequacy of such teaching and learning resources posed a critical challenge for students to develop and acquire relevant competencies that were required by the industry. Thus, the only practical option which was left by the TVET institutions was to engage their students for industrial attachments so that students could have a real practical experience on latest equipment which the TVET institutions could not afford to procure. However, we can as well conclude that very few students had an opportunity to practice industrial attachments due to the small industrial base in the country and skeptical tendencies by some industrial owners to accept the students.

\section{Recommendations}

In this study we recommend that TVET institutions should be urgently equipped with relevant and adequate teaching and learning resources so as to maintain the production of quality graduates. Researchers in this study further recommend that TVET College and industrial partnership could allow 
TVET providers to take advantage of specialized skills offered by certain industries and improve the quality of competency acquisition in technical education. This would also address the challenge of skills gap between TVET institutions and industries and improve on quality students' competencies which could make them self-reliant as well as to cope with challenges of unemployment. The current labour market requires TVET graduate with high and appropriate technical skills which are in line with the specialization they studied. This is what will help lower unemployment as such graduates will have had acquired employability skills. Additionally, one of the things that the Ministry of Higher Education (MoHE) needs to seriously and urgently consider is to fund TVET institutions adequately so that these institutions can be managed well. No wonder Mubanga, Hock, Karim and Mulenga (2019, p. 105) recommended in their study that;

Adequate funding should be provided for successful technical and vocational education and training, as findings indicated that poor funding to the TVET sector, the training institutions and the TVET regulator had compromised the delivery of quality TVET and was one of the major factors contributing to the lack of skills and the skills gaps in most of the graduates

This will only be possible if MoHE in Zambia attends to the challenges that TVET institutions are facing as explained in this study.

\section{Reference}

Barky, A. L. (2005). Selecting Teaching Methods and Materials. Agricultural Education Magazine. Agricultural Research Institute, Umudike.

Brown, M. (1994). A Collection of Readings Related to Competency-based Training Education. Florida: Praken publication.

Choy, S. and Hauka, S. (2009). International hand book of education for the changing world of work: Industrial attachment for instructors in TVET delivery. Australia: Springer Link.

Creswell, J. W. (2012). Educational Research: Planning, Conducting and Evaluating Quantitative and Qualitative Research (4th Ed). University of Nebraska, Lincoln.

Creswell, J. W., \& Plano, C. V. L. (2011). Designing and conducting mixed methods research (2nd Ed.). Thousand Oaks, CA: Sage.
Dadi, L. (2014). Effectiveness-Based TVET Curriculum in Ethiopia: The Case of TVET Institutions of Oromia Regional State. PhD Thesis. Addis Ababa University

Daksa, D. (2013). Current Practices and Prospects of Technical and Vocational Education and Training (Tvet): The Case of East Wollega Zone. PhD. Thesis. Jimma University.

Dasmani, A. (2011). Challenges facing technical institute graduates in practical skills acquisition in the Upper East Region of Ghana. In Asia-Pacific Journal of Cooperative Education, 2 (2), 67-77. doi: 10.1.1.688.8559

Gasson, S. (2004). Rigor in grounded theory research: An interpretive perspective on generating theory from qualitative field studies. In M. E. Whitman \& A. B. Woszczynski (Eds.). The handbook of information systems research (79-102). Hershey, PA: Idea Group.

Hamweete, W. (2008). Performance of Selected Technical Education, Vocational and Entrepreneurship Management Boards in Luanshya District of Zambia's Copperbelt Province. M.Ed. Dissertation. The University of Zambia.

Indoshi, C., Wagah, O. and Agak, O. (2010). Factors that determine students' and teachers' attitudes towards Art and Design curriculum. International Journal of Vocational and Technical Education, 2(1), 917.

Keiser, J., Lawrenz, F. and Appleton, J. (2004). Technical Education Curriculum Assessment. Journal of Vocational Education Research, 29(3) 181-194. http:/eric.ed.gov/?id:EJ720026

Kigwilu, C. P. (2014). Determinants of Effective Implementation of Artisan And Craft Curriculum in Catholic Sponsored Community Colleges in Nairobi Region, Kenya. PhD Thesis. The Catholic University of Eastern Africa.

Kigwilu. C. P. and Akala, J. W. (2017). Resource Utilisation and Curriculum Implementation in Community Colleges in Kenya. International Journal for Research in Vocational Education and Training (IJRVET), 4(4), 369-381. https://doi.org/10.13152/JJRVET.4.4.4

Ministry of Education, (1996). Educating Our Future: National Policy on Education. Lusaka: Zambia Education Publishing House. 
Morrow, L. S. (2005). Quality and Trustworthiness in Qualitative Research in Counseling Psychology. Journal of counselling psychology, 52 (2004), 636-755.

Mubanga, P., Hock, O.Y., Karim, A.M., Senteri, Z., Mulenga, I. M. and Preckler, M. (2019)

Harnessing Technical and Vocational Education and Training and Entrepreneurship Education to Address Unemployment in Lusaka Province, Zambia. Open Journal of Social Sciences, 7, 153-179. https://doi.org/10.4236/jss.2019.75013.

Mubanga, P., Hock, O. Y., Karim, A. M. and Mulenga, I. M. (2019). Methods of Financing

Technical and Vocational Education and Training and Entrepreneurship Education to Support Skills Development in Lusaka Province, Zambia. International Journal of Research and Scientific Innovation. 4 (4), 96107.

Mulenga, I. M. and Kabombwe, Y. M. (2019). A Competency-Based Curriculum for Zambian

Primary and Secondary Schools: Learning from Theory and Other Countries in the World. International Journal of Education and Research. 7 (2), 117-130. http://www.ijern.com/journal/2019/Februa ry-2019/10.pdf.

Mulenga, I. M. and Kabombwe, Y. M. (2019). Understanding a Competency-Based

Curriculum and Education: The Zambian Perspective. Journal of Lexicography and Terminology. 3 (1). 106-134.

Mupinga, M., Busby, R., and Ngatiah, W. (2006). Postsecondary technical and vocational education institutions in Kenya: Needs and challenges. International Journal of Vocational Education and Training, 14(1), 21-35.

Mwila, K. (2016). Education and Skills Development: Examining the Effectiveness of Technical Education, Vocational and Entrepreneurship Training in Solwezi District of Zambia. M.Ed Dissertation. The University of Zambia.

Ngure, S. W. (2013). Stakeholders' Perceptions of Technical, Vocational Education and Training: The Case of Kenyan Micro and Small Enterprises in the Motor Vehicle Service and Repair Industry. PhD Thesis. Edith Cowan University.
NICHE, (2010). NICHE Strategy on Technical and Vocational Education and Training (TVET). Nuffic: NICHE.

Nkanza, P. K. (2007). The TEVET Qualifications Framework-a tool for economic growth. Lusaka: A paper presented at a workshop 2007.

Onwuegbuzie, A.J. \& Frels, R.K. (2013). Methodology training workshop for PHD trainers and supervisors. Nairobi: Kemit Publishers.

Pallant, J. (2007). SPSS Survival Manual. A Step by Step Guide to Data Analysis Using SPSS for Widows. Sydney: Ligare Book Printer.

Republic of Zambia (2017). Seventh National Development Plan 2017-2021. Lusaka: Republic of Zambia

Sahlberg, P. (2012). The Most Wanted Teachers and Teacher Education in Finland. In L.

Darling-Hammond and A. Lieberman (Eds.), Teacher Education around the World: Changing Policies and Practices. New York: Routledge.

Salimu, M. M. (2007). An Evaluation of the Performance of the TVET Management Boards in Improving the Quality of Training: The Case of Lusaka and the Copperbelt. PhD Thesis. Kitwe: Copperbelt University.

Sharma, A. (2008). Technical Vocational Education and Training (TVET) in Africa. Addis Ababa: AU.

Shenton, K. A. (2004). Strategies for ensuring trustworthiness in qualitative research projects. Education for information, 22 (20), 63-75.

Simukanga, S. and Jacob, W. J. (2018). Establishing a National Higher Education Accreditation Framework: Challenges and Opportunities in Zambia. Excellence in Higher Education. 8 \& 9, (1\&2). 1-7. doi: 10.5195/ehe.2018.159

TEVETA. (2016). Report of the Registration and Accreditation Sub-Committee of the TEVETA Board. Lusaka: TEVETA.

TEVETA, (2015). TEVETA partners with commonwealth of learning on open distance and flexible learning training system. TEVETA, 15 (3), 1-17.

TEVETA. (2010). Annual Report: 2010. Skills for development. Lusaka: TEVETA

Umar, I. Y. and Ma'aji, A. S. (2010). Repositioning the Facilities in Technical College Workshops for Efficiency: A Case Study of North Central Nigeria. Journal of Teacher Education: 47 (3), 1-9. 
Umunadi, E. K. (2011). Provision of Equipment and Facilities in Vocational and Technical Education for Improving Carrying Capacity of Nigeria's Tertiary Institution. In the Proceedings of the 1st International Technology, Education and Environment Conference. Held at Omoku-Nigeria,

UNESCO. (2016). Strategy for Technical and Vocational Education and Training (TVET) (2016-2021). UNESCO.

Wallernborn, M. (2010). Vocational Education and Training and human Capital Development:
Current Practice and Future Options. European Journal of Education, 45 (2), 181198. https://doi/abs/10.1111/j.14653435.2010.01424x.

Zulu, J. and Mulenga, I. M. (2019). Teachers' pedagogical content knowledge, curriculum designing, and Students' comprehension of secondary school ordinary level physics in Lusaka, Zambia. UNESWA Journal of Education, 2 (1), 273-288. 